\title{
RESEARCH PAPER \\ PARTICIPATORY EVALUATION OF DROUGHT TOLERANT MAIZE VARIETIES IN THE GUINEA SAVANNA OF GHANA USING MOTHER AND BABY TRIAL DESIGN
}

\author{
S. S. J. Buah*, J. M. Kombiok, R. A. L. Kanton, N. N. Denwar, A. Haruna, A. N. Wiredu \\ and M. S. Abdulai \\ CSIR-Savanna Agricultural Research Institute (CSIR-SARI), P.O. Box 52, Tamale, Ghana \\ "Corresponding author, e-mail: ssbuah@yahoo.com
}

\begin{abstract}
Maize (Zea mays) is a major food crop in Ghana but grain yields are low as a result of drought and low soil fertility. This study evaluated drought tolerant maize varieties in 2008 and 2009 in the Guinea savanna of Ghana using researcher-managed mother and farmer-managed baby trial design. Mean grain yields ranged between 2574 and $3462 \mathrm{~kg} / \mathrm{ha}$ for the mother trials and 1460 and $2328 \mathrm{~kg} / \mathrm{ha}$ for baby trials. Several improved varieties performed better than the best local varieties, but two preferred varieties, TZEE Y POP STR QPM CO and EVDT W 99 STR QPM CO which produced $35-52 \%$ more grain than the best local varieties of similar maturity rating were released in 2010. Farmers have multiple criteria for evaluating maize varieties apart from yield, though yield, larger cob and grain size were the three key criteria used by farmers to select and rank varieties. Researchers should incorporate farmers' preferences in selecting varieties in the breeding process in order to increase likelihood of adoption of the varieties.
\end{abstract}

Keywords: Drought-tolerant maize, farmer preference, mother and baby, participatory

\section{INTRODUCTION}

Maize (Zea mays) is an important staple food crop in West and Central Africa (WCA), yet yields are low as a result of mainly low soil fertility, Striga infestation and drought stress (Badu-Apraku and Lum, 2010). Early-season drought may reduce maize seedling establishment, while drought at flowering or grain filling stages could reduce yield or a complete crop failure may result (Ashley, 1999). Maize production provides livelihoods for millions of subsistence farmers in WCA, thus, increasing the productivity of maize-based cropping systems could increase and stabilize rural incomes, alleviate poverty and reduce food insecurity in this region (Kamara et al., 2006).

Through collaborative efforts between the International Institute of Tropical Agriculture (IITA) and national maize improvement programmes in WCA, several maize varieties that are either drought tolerant (DT) or mature earlier to escape drought have been developed and evaluated under researcher-managed conditions 
in Ghana (Badu-Apraku et al., 2009). Nonetheless, little information is available on the performance of these varieties in farmer-managed trials and the potential for their adoption based on farmers' preferences. The traditional topdown approaches to agricultural research and extension could be blamed for the low adoption of technologies and for the development of technologies that are irrelevant to the small farmers' priorities and resource constraints (Chambers et al., 1989; Mulatu and Belete, 2001; Jalleta, 2004). In developing and selecting new varieties, breeders may discard many varieties because of traits considered undesirable to them; though these traits may be of interest to farmers. As farmers are the ultimate beneficiaries of the maize varieties, there is the need to involve farmers in selecting suitable varieties under their socio-economic and agroecological circumstances at very early or advanced stages. This study was conducted under the auspices of the Drought Tolerant Maize for Africa (DTMA) project supported by the Bill and Melinda Gates and Howard G. Buffet foundations to obtain farmers' input and feedback on the selection of DT maize varieties that are in advance stages of development or ready for release using mother and baby trial design. The mother and baby trial approach is an on-farm participatory mechanism to introduce and test a range of technology options suited to a heterogeneous community (Snapp 2002). This onfarm research paradigm consists of a central researcher-managed "mother trial" comprising all tested varieties and satellites or "baby trials" which are farmer-managed trials in which a subset of varieties from the mother trial are tested (De Groote et al., 2002). The design aims to bridge the gap between breeders and farmers and also ensure that new varieties satisfy farmers' preferences and suit their socioeconomic situation (Banziger and de Meyer, 2000).

\section{MATERIALS AND METHODS}

Field trials were conducted to assess farmers' input and feedback on the selection of DT maize varieties using mother and baby trial design during the 2008 and 2009 cropping sea- sons (June-October) at two sites (Kpongu in the Wa Municipality and Silbelle in the Sissala West District) in the Upper West region (UWR). The UWR is located in the northern Guinea savanna of Ghana stretching from Latitude $9^{\circ} 35^{\prime} \mathrm{N}$ to $11^{\circ} 00^{\prime} \mathrm{N}$ and from Longitude $01^{\circ} 25^{\prime} \mathrm{E}$ to $02^{\circ} 50^{\prime} \mathrm{E}$, and at an altitude of 200 $350 \mathrm{~m}$ above sea level. Both sites are characterized by erratic and poorly distributed unimodal rainfall, averaging about $1000 \mathrm{~mm}$ per annum (MSDG, 1997). Total annual rainfall was 1171 $\mathrm{mm}$ in 2008 and $1086 \mathrm{~mm}$ in 2009. The predominant soils are sandy loam (classified as Typic-plinthic Paleustalf according to the U.S. Soil Taxonomy) by texture within the $0-30 \mathrm{~cm}$ soil depth. The soils are inherently low in natural fertility and have a low moisture retention capacity. On average, the soils in the region have a $\mathrm{pH}$ of $6.0-6.8\left(1: 1 \mathrm{H}_{2} \mathrm{O}\right), 0.5-1.3 \%$ organic matter, $0.01-0.07 \mathrm{mg} / \mathrm{kg}$ total $\mathrm{N}, 35.2 \mathrm{mg} /$ $\mathrm{kg}$ exchangeable $\mathrm{K}$, and $2.0-7.4 \mathrm{mg} / \mathrm{kg}$ available P (Bray-1 P) (FAO, 2005).

At each site, one mother and 10 baby trials of extra-early/early (80-95 days to maturity) varieties and medium varieties (100-110 days to maturity) were evaluated on farmers' fields. The extra-early/early maturity mother trial consisted of seven varieties from IITA (EVDT W 99 STR QPM C0, 2004 TZE W POP STR C4, 2004 TZE Y POP STR C4, TZEE Y POP STR QPM C0, TZEE Y POP STR C4, TZE COMP 3 C1 and 2004 TZE W DT STR C4), one farmers' variety and a released quality protein maize (QPM) variety (Akposoe). The medium maturity mother trial consisted of four varieties from IITA (TZU TSY W SGY SYN, DT SR W C0F2, DT SYN 1W, and IWD C2 SYN F2), a released QPM hybrid (Mamaba) and farmers' variety.

The mother trials were planted at Silbelle and Kpongu on $12^{\text {th }}$ and $14^{\text {th }}$ July in 2008 and on $14^{\text {th }}$ and $22^{\text {nd }}$ July in 2009 , respectively. The experimental design was a randomized complete block with four replications per site. Each plot consisted of 6 rows, $6.0 \mathrm{~m}$ long, spaced 0.75 and $0.80 \mathrm{~m}$ apart for extra-early/early and 
medium varieties, respectively. Spacing between plants within a row was $40 \mathrm{~cm}$. Three seeds were planted per stand and thinned to two per stand at one week after planting (WAP), to give a target population of 66,600 and 62,500 plants/ha for extra-early/early and medium maize, respectively. Weeds were controlled using hand hoe at 2 and 4 WAP. Fertilizer was applied at a rate of $64-38-38 \mathrm{~kg} / \mathrm{ha}$ as $\mathrm{N}, \mathrm{P}_{2} \mathrm{O}_{5}$ and $\mathrm{K}_{2} \mathrm{O}$, respectively. All the $\mathrm{P}$ and $\mathrm{K}$ as well as $38 \mathrm{~kg} \mathrm{~N} / \mathrm{ha}$ were applied in the form of NPK (15:15:15) at $1 \mathrm{WAP}$ and the remaining $26 \mathrm{~kg}$ $\mathrm{N} /$ ha was top-dressed at $4 \mathrm{WAP}$ in the form of urea. Ten baby trials in each maturity group were planted at each location between $15^{\text {th }}$ and $27^{\text {th }}$ July in both years. Each baby trial consisted of three improved varieties planted alongside a farmer's variety and a plot measured $20 \times 20 \mathrm{~m}$. Varieties tested in the baby trials were selected from the mother trials by farmers and each farmer represented a replicate.

Data on plant height at flowering, flowering date (days to $50 \%$ anthesis) were collected. Grain yield was determined by harvesting the centre two rows of each plot after physiological maturity in the mother trial and an area of $10 \mathrm{x}$ $10 \mathrm{~m}$ in the baby trials. Grain yield was calculated based on $80 \%$ shelling percentage and corrected to a $15 \%(150 \mathrm{~g} / \mathrm{kg})$ moisture basis. Farmers' preferred varieties were identified during field days at physiological maturity using preference ranking based on earliness, grain yield, grain size, grain colour, drought tolerance, and marketability. Each criterion was scored on a scale of 1-9 (1 = very important and 9 = least important) (De Groote et al., 2002). To determine which varieties were considered comparatively superior and more likely to be adopted, the farmers gave an overall score to each variety, using a scale of 1-9 for the 9 extra-early/early and 1-6 for the 6 medium maturing varieties $(1=$ very good and 6 or $9=$ very poor depending on maturity group) (De Groote et al., 2002).

Data collected were subjected to an analysis of variance (ANOVA) with the Statistical Analysis System (SAS) for Windows 9.1 (SAS Institute Inc., Cary, NC) to establish varietal differences and interaction effects on crop development and yield. Fixed effects were varieties, and year, location and replication were treated as random effects. Varietal effects and all interactions were considered significant at $P \leq 0.05$. Where the ANOVA showed significant differences of variables between treatments, means were separated using Least Significant Difference (LSD). Descriptive statistics (simple percentages) were used to compare frequencies of respondents with respect to farmers' choice of variety and their perceptions on the varietal choice.

\section{RESULTS}

Prolonged pre-season drought in June delayed planting until mid-July. This was followed by wet conditions which affected plant growth at both sites. At each site, year $\mathrm{x}$ variety interaction as well as year effect were not significant for any parameter. Therefore, data were pooled across years and only the main effects of variety are presented for each site because site $\mathrm{x}$ variety and site effects were significant.

\section{Extra-early/early mother trials}

Days to mid-anthesis among the IITA varieties ranged from 49 to 52 at Kpongu and 49 to 53 at Silbelle (Table1). The farmers' variety was the tallest $(>2.0 \mathrm{~m}$ ) and took 57 and 63 days to reach mid-anthesis at Silbelle and Kpongu, respectively. Farmers' variety matured late and also did not produce higher yields. Four varieties (EVDT W 99 STR QPM C0, 2004 TZE W DT STR C4, 2004 TZE Y POP STR C4 and 2004 TZE W POP STR C4) had higher yields than Akposoe and the farmer's variety at Kpongu. Yields of the IITA varieties at Silbelle were comparable to that of the farmers' variety except for 2004 TZE W DT STR C4, which had $38 \%$ (or $889 \mathrm{~kg} / \mathrm{ha}$ ) more grain than the farmers' variety.

\section{Extra-early/early baby trials}

In the baby trials, the farmers' variety again grew taller and flowered late (Table 2). At 
Buah et al.

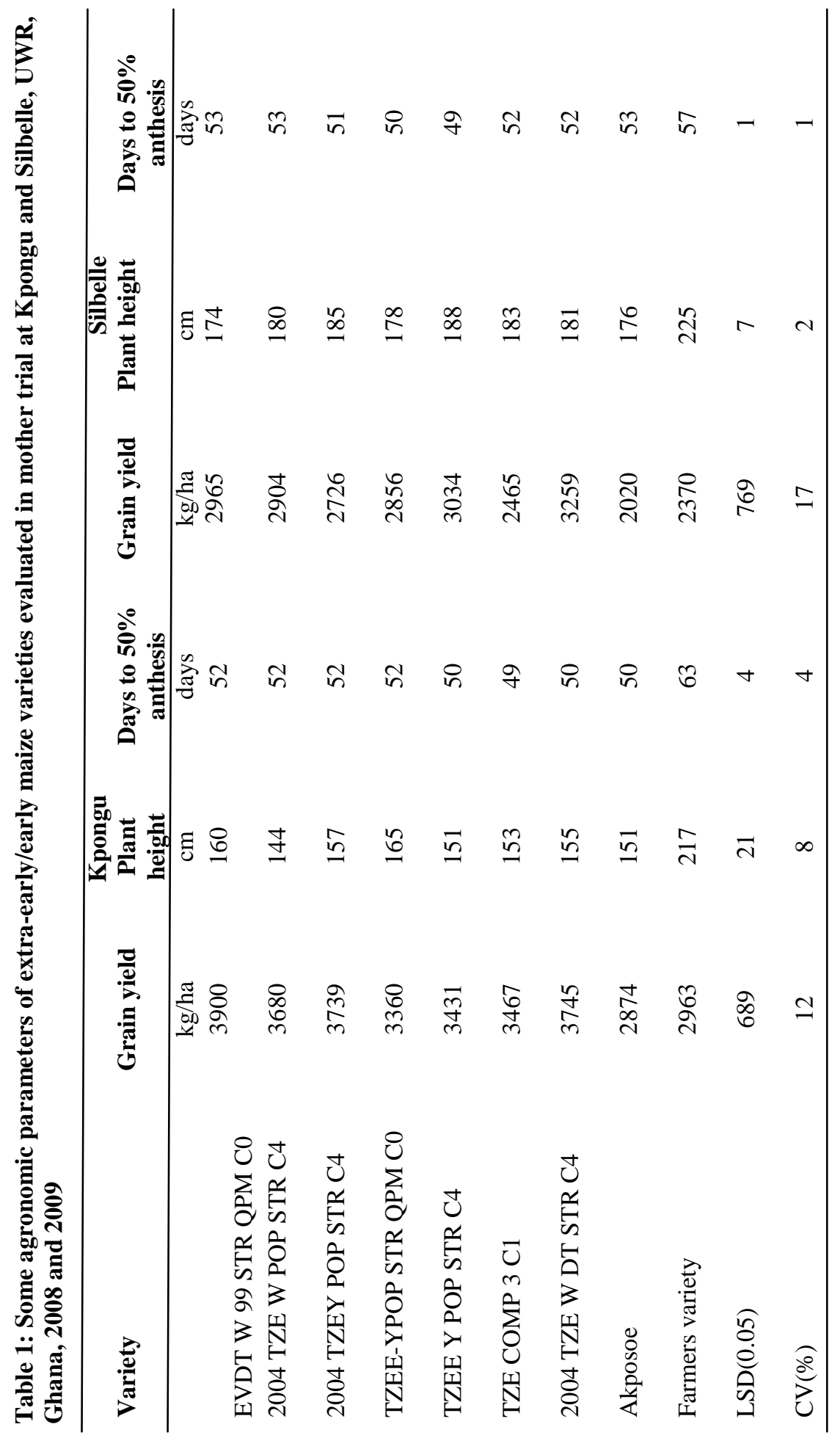

Journal of Science and Technology $\odot$ KNUST August 2013 
Kpongu, the farmers' variety, two IITA varieties (2004 TZE W POP STR C4, TZE Comp3 C1) and Akposoe had similar but lower yields. The other five varieties produced $67-100 \%$ more grain than the farmers' variety. Yield of the Striga resistant variety (TZEE Y POP STR C4) was double the yield of the farmers' variety at Kpongu. Genotypic differences in terms of yield were not significant at Silbelle.

\section{Medium mother trials}

The farmer's variety was the tallest $(182 \mathrm{~cm})$ and took 61 days to reach mid-anthesis at Silbelle (Table 3). Differences in days to midanthesis and plant height were not significant at Kpongu. Mamaba had the highest yields which were $978 \mathrm{~kg} / \mathrm{ha}$ (or 44\%) and $1636 \mathrm{~kg} / \mathrm{ha}$ or $73 \%$ more than the farmers' variety at Silbelle and Kpongu, respectively. Additionally, Mamaba produced $31 \%(753 \mathrm{~kg} / \mathrm{ha})$ more grain than TZU TSY W SGY SYN which had the lowest yield $(2465 \mathrm{~kg} / \mathrm{ha})$ in Silbelle. All the varieties except TZU TSY W SGY SYN outyielded the farmers' variety at Silbelle.

\section{Medium baby trials}

The farmers' variety was the tallest and flowered 6 days later than Mamaba (51 days) at Silbelle and 9 days later than TZU TSY W SGY SYN at Kpongu (Table 4). Mamaba and IWD C2 SYN F2 had the highest yields at Kpongu and Silbelle, respectively. The farmers' variety had the lowest yield at both locations. Mamaba significantly out-yielded the farmers' variety by $46 \%$ (707 kg/ha) in Silbelle and $164 \%$ (2283 kg/ha) in Kpongu, while IWD C2 SYN F2 produced $54 \%(821 \mathrm{~kg} / \mathrm{ha})$ more grain than the farmer's variety in Silbelle. Also, DT SYN 1W produced 36-87\% (or 561$1207 \mathrm{~kg} / \mathrm{ha}$ ) more grain than the farmers' variety at both locations.

\section{Evaluation of varieties}

Across years, 160 farmers (comprising 124 men and 36 women) attended field days at the mother trial sites at maturity. Key criteria used by farmers to select and rank varieties were grain yield, cob size, grain size, drought toler- ance, earliness, market value, grain colour, plant height and tolerance to pests and diseases (Table 5). Farmers' overall scores for each variety were averaged over the site-years, resulting in an average score, which was used to rank the varieties. On average, the three most important selection criteria for farmers were grain yield, cob size and grain size. Drought tolerance, earliness and market value were of intermediate significance. Grain colour, plant height and tolerance to pests and diseases were not critical selection criteria to the farmers.

Among the extra-early/early varieties, 2004 TZE-Y-POP STR C4 was ranked first by most farmers, followed by EVDT W 99 STR QPM C0 and 2004 TZE-W-POP STR C4 in that order (Table 6). Researchers ranked EVDT W 99 STR QPM C0 first and 2004 TZE W DT STR C4 second. However, these two varieties were ranked second and seventh respectively, by farmers. Researchers and farmers similarly ranked farmers' variety eighth and TZE COMP $3 \mathrm{C} 1$ last. Among the medium varieties, researchers and farmers ranked Mamaba, DT SYN $1 \mathrm{~W}$, TZU TSY W SGY SYN and farmers' variety first, third, fifth and last respectively. Nevertheless, farmers ranked DT SR W C0 F2 second, while researchers ranked IWD C2 SYN F2 second. In all cases, farmers' variety preferences did not agree exactly with those of researchers.

\section{DISCUSSION}

The impact of DT maize is yet to be felt in the drought prone areas of the Guinea savanna of Ghana. It was therefore necessary to involve farmers in the zone in the selection of these improved DT varieties through participatory variety selection process. Most farmers who evaluated the DT maize have a long tradition (> 15 years) of growing maize. In this study, mean yields from researcher-managed trials were higher than the national average yield of $1.7 \mathrm{t} /$ ha (MoFA, 2010) as a result of the use of improved seed and good cultural practices. Moreover, farmers recognized that improved varieties perform better if accompanied by recomm- 


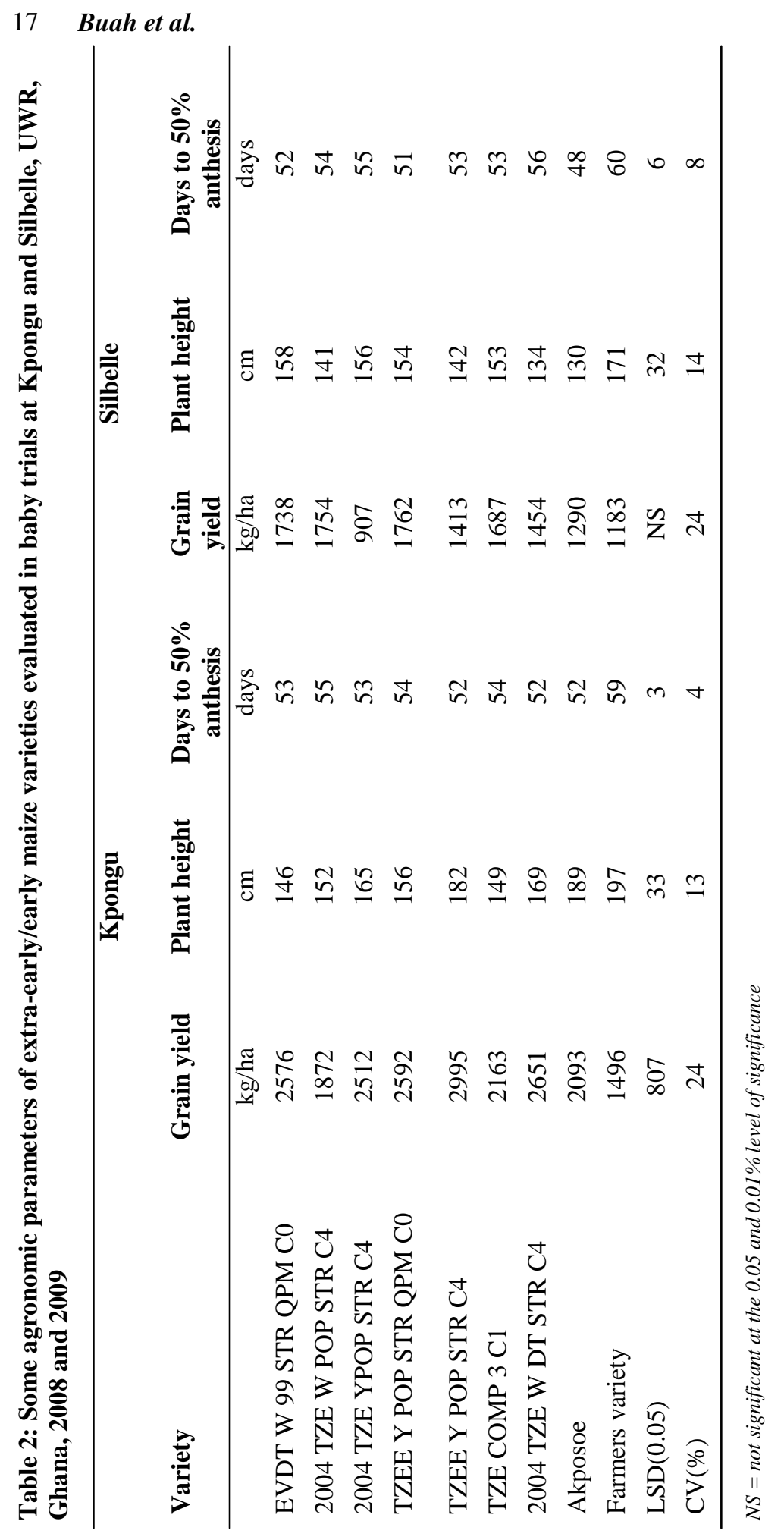

Journal of Science and Technology @ KNUST August 2013 
Participatory selection of maize varieties...

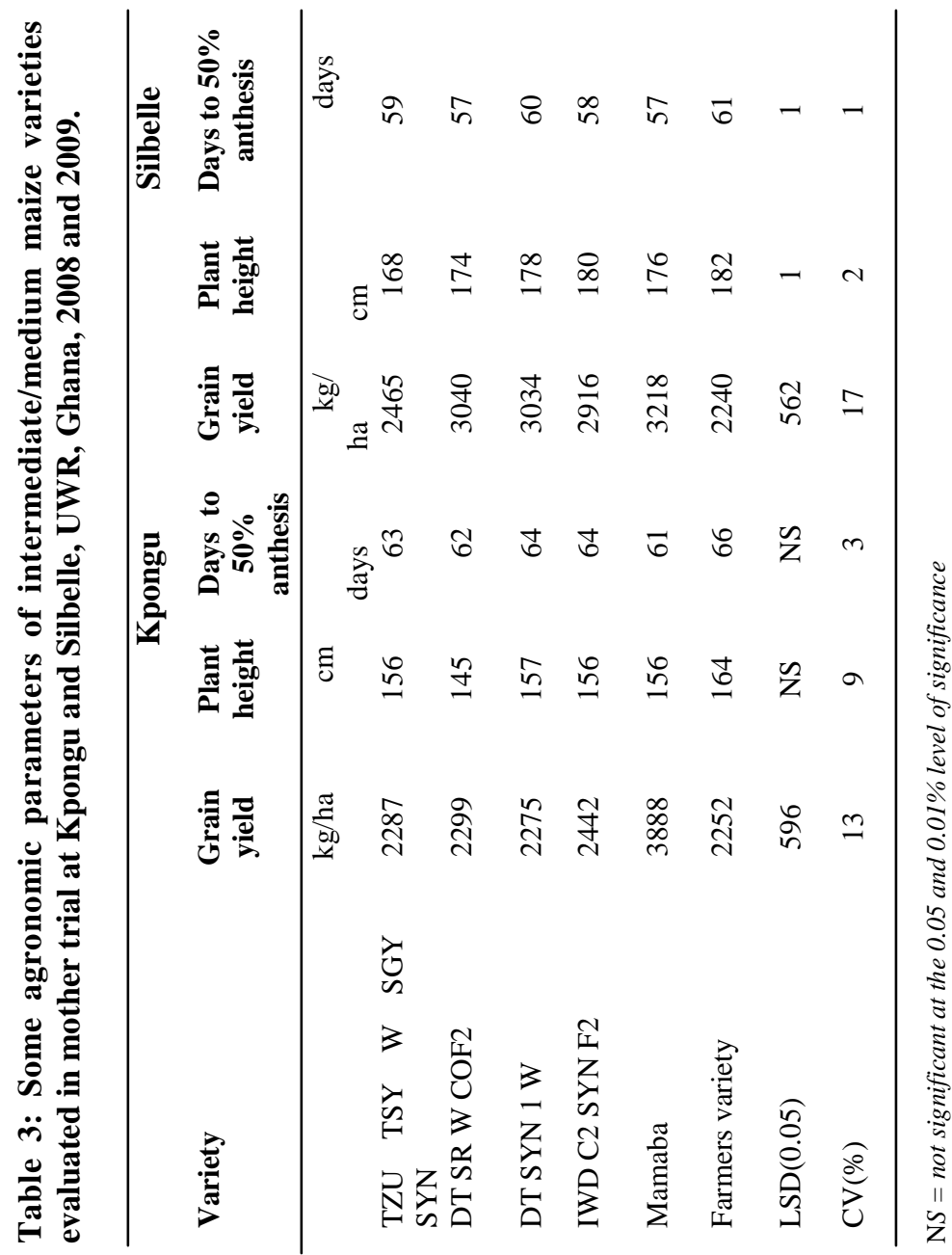

ended cultural practices. The farmer varieties were taller and visually more prone to lodging (data not shown). Additionally, some farmer varieties had significantly lower grain yields, probably because less biomass was partitioned to the grains. Contrary, some improved varieties and the farmers' variety had similar yields. This was not surprising because the farmers' varieties were probably improved varieties previously bought from seed dealers or supplied by other development organizations over the past years. Hence, the word "farmer variety" should be used with caution as the use and/or recycling of improved seed is widespread in
Ghana. Very high coefficient of variation (higher CV) showed by the farmer-managed baby trials for both maturity groups was probably due to poor management of the trials by farmers.

Farmers identified grain yield, cob size, grain size and earliness as the most important criteria for adoption of maize varieties. Bigger cobs and grain sizes were preferred because farmers believe that grains from bigger cobs produce higher yields in subsequent generations. Earliness was also considered an important criterion because early maturity allows the crop to es- 

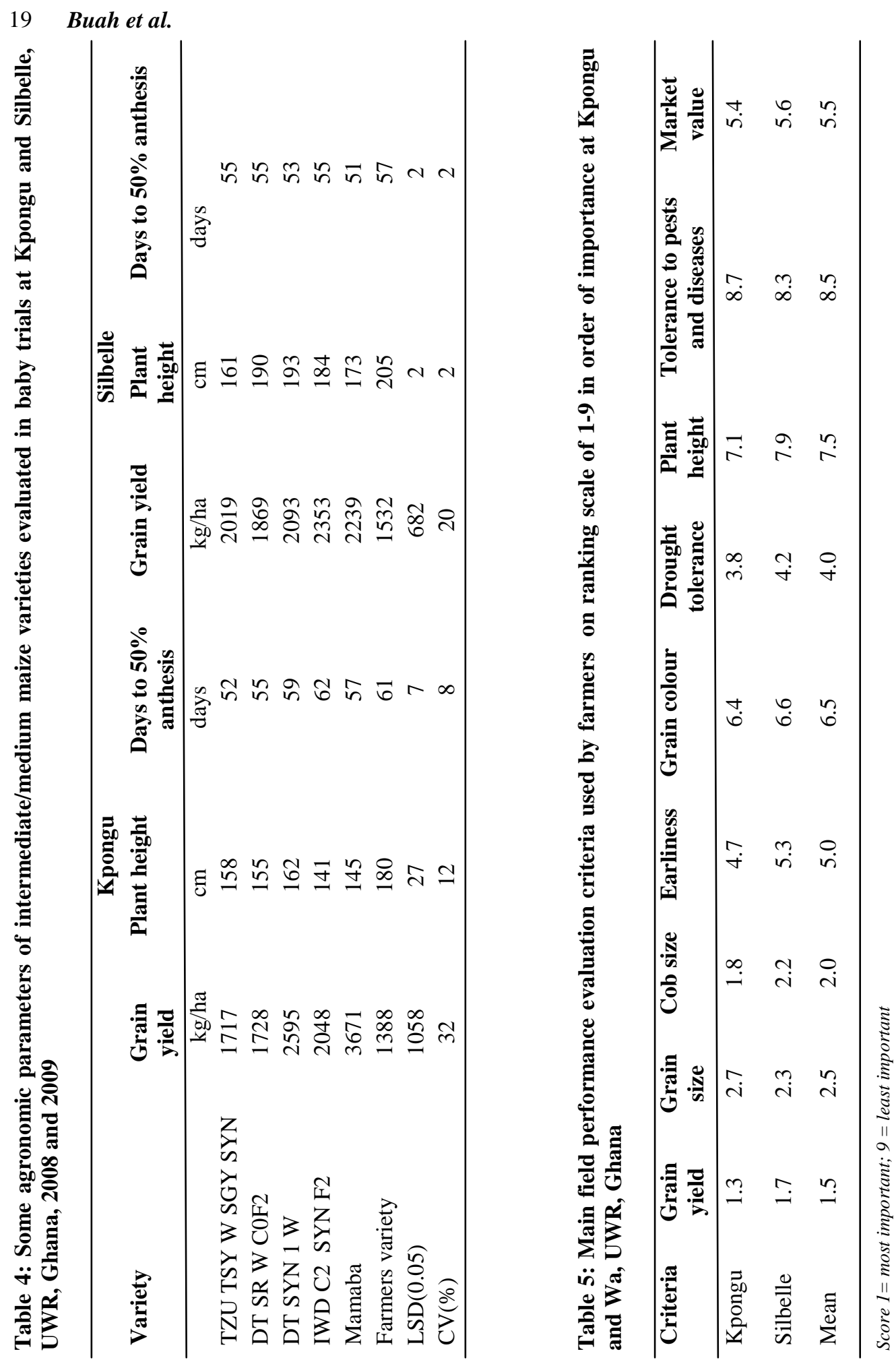

Journal of Science and Technology @ C KNUST August 2013 


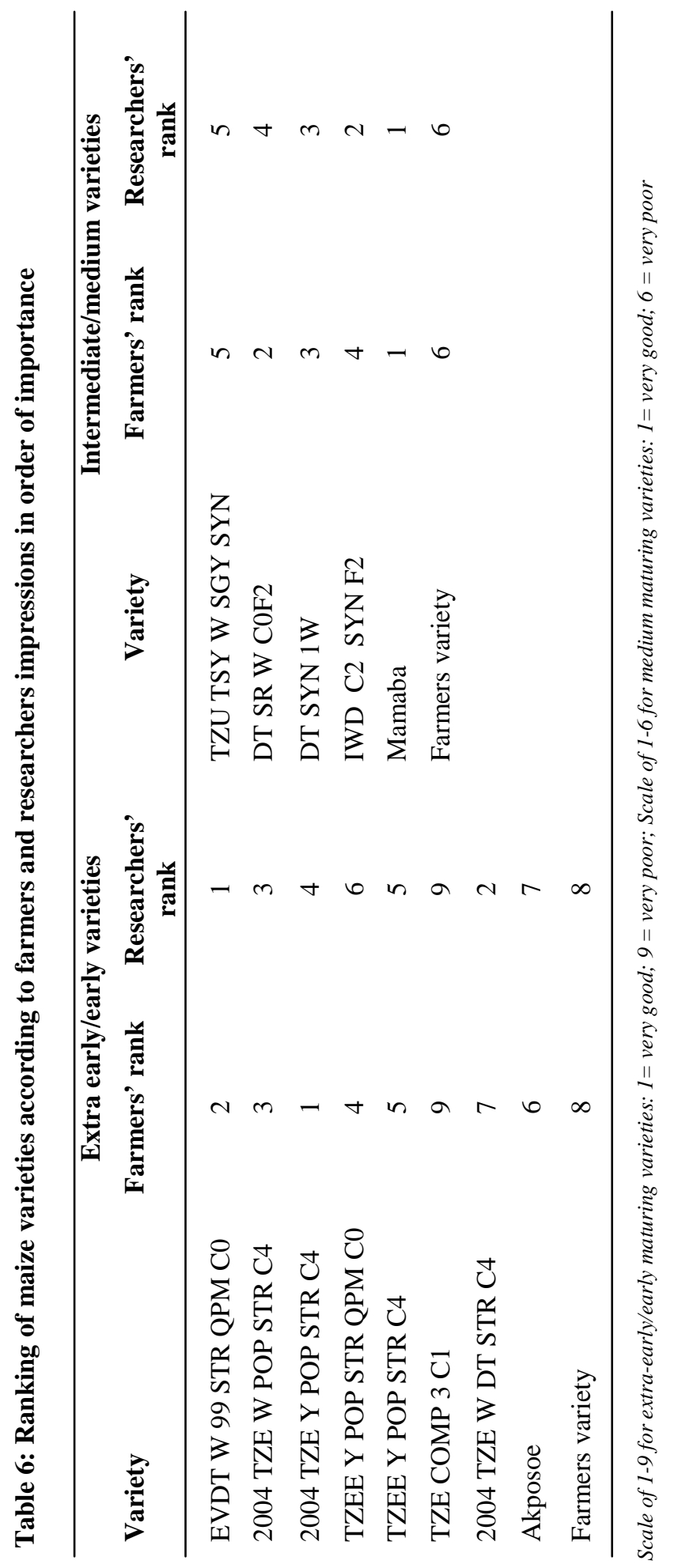

Journal of Science and Technology @ KNUST August 2013 


\section{Buah et al.}

cape drought and ensure early and quick provision of cash and food to households to bridge the hunger gap. Early genotypes have advantage over medium or late ones in environments where the rains begin late and/or end early (Badu-Apraku et al., 2009). Some farmers preferred the extra-early QPM variety with yellow endosperm (TZEE Y POP STR QPM C0) for considerations of household food security, as their emphasis was more on earliness than high yields. Yellow maize is mostly consumed as green maize which is produced at the onset of rainy seasons before the rains are fully established. Extra-early yellow maize matures at a time when the demand for roasted or boiled maize exceeds its supply; hence its price tends to be higher. This tends to encourage some farmers to prefer yellow maize to white maize.

The variety (2004 TZE Y POP STR C4) showed good physical traits that appealed to farmers and was therefore ranked first by most farmers, but researchers ranked it fourth based on its grain yield. Researchers and farmers however, ranked the worst varieties (TZE COMP $3 \mathrm{C} 1$ and the farmer varieties) in the same order. Although 2004 TZE W DT STR C4 is known to have high yield potential and often show good performance when Striga infestation and drought conditions occurred simultaneously, farmers were not aware of these attributes and therefore ranked it seventh, but researchers ranked it second based on grain yield. Through this participatory variety evaluation process, farmers realized that the attributes of drought and Striga tolerance as well as the QPM trait in TZEE Y POP STR QPM C0 and EVDT W 99 STR QPM C0 were desirable to them. This corroborates the results of Nkongolo et al. (2008) who reported that participatory variety selection adds information on farmers' perceptions of plant and grain traits and ensures that new varieties satisfy their preferences and suit their socio-economic situations. The two varieties combine high yields with elevated levels of lysine and tryptophan and this could reduce food insecurity and malnutrition, especially in children in WCA where protein deficie- ncy among children is common because meat, fish and eggs are beyond the means of the average family. As reported by Mekbib (2006) if farmers are excluded in the variety development process they often reject new varieties that do not fulfill their multipurpose values. Results of this study suggest that farmers are sometimes reluctant to adopt good varieties either due to inadequate knowledge or lack of extension advice and the adoption rate of such unknown varieties could have been low.

According to Abebe et al. (2005) farmer's preferences in some cases often coincided with the breeders' selection as was the case with the similar order of ranking of Mamaba, DT SYN 1W, TZU TSY W SGY SYN and the farmers' variety by both researchers and farmers. The hybrid, Mamaba was ranked first because of its high yield potential and bigger cobs. Under good management, hybrid maize is expected to have higher grain production potential than OPVs of similar maturity rating. The variety, IWD C2 SYN F2 was ranked second by researchers and fourth by farmers. The reverse was true for DT SR W COF2. In this study, farmers' perceptions and preferences for the best maize varieties were not in exact agreement with researchers selection, because in some instances; the farmers expressed their preferences differently. Generally, farmers are rational decision makers as they make choices in order to maximize the returns from their production activities. Therefore they should be included in the maize variety selection process in order to incorporate their preferences in selection of varieties in the breeding programme as this may increase likelihood of adoption of the varieties, especially where the research directly affects their livelihoods as suggested by other researchers (Ceccarelli et al., 2001; Jalleta, 2004). According to Selener (1997) research that does not involve farmers as active members in the early phases faces the risk of developing technologies of little relevance and of low adoption. 
Several of the adapted DT maize varieties which were preferred by both researchers and farmers were ideal replacement for the farmers' local varieties. These varieties could be used either as cultivar per se to escape drought stress during the later part of the cropping season or be used as germplasm sources for breeding programmes for developing high yielding varieties adapted to drought prone areas. Several farmers retained seed from previous harvests of the baby trials for future planting. Though not advisable, there is convincing evidence that farmers are willing to adopt the varieties since they are confident of their high yields. According to some researchers, increasing farmers' access to their preferred varieties would result in a faster rate of diffusion through farmer-to-farmer seed exchange (Mulatu and Belete, 2001). Thus, farmers are likely to either adopt or adapt a technology to their own needs and environment if they are involved in the technology development process. Six preferred varieties were recommended to the National Variety Release Committee for release, but only two varieties (TZEE Y POP STR QPM C0 and EVDT W 99 STR QPM C0) which were QPM were approved and released nationally as CSIR -Abontem and CSIR-Aburohemaa, respectively in 2010. The varieties' characteristics such as earliness, quality protein traits, simultaneous drought and striga tolerance, yield potential, and endosperm characteristics were highlighted in their release protocol. It is worthy of note that by the time of release, farmers were already growing them, and a substantial amount of seed had been distributed via the informal seed distribution/marketing system.

\section{CONCLUSION AND RECOMMENDA- TIONS}

Results of this study showed that farmers have multiple criteria for evaluating maize varieties apart from yield, though yield was the major parameter for selecting varieties they grow. Incorporating farmers' preferences in selection of varieties in the breeding process may increase the likelihood of adoption of the varie- ties. Whereas breeders cannot incorporate all the desired attributes, the key attributes should be included in particular varieties and many varieties could be bred focusing on the demands of different farmer groups. Highlighting QPM extra-early varieties, for bridging hunger gap, escape of drought prone period as well as for cash and food for the family should be further looked at by maize breeders, especially those with yellow endosperm. Nonetheless, farmers may sometimes be reluctant to adopt good varieties either due to inadequate knowledge or lack of extension advice. The study highlighted the need for re-orienting agricultural research towards involving farmers at the appropriate stages of technology identification and development.

\section{ACKNOWLEGDEMENTS}

We are grateful to the IITA/DTMA Project for funding this study. We thank Ibrahim Hashim, Solomon Antuona, Hariuna Ali Kende and Francis Alemawor for their role in the data collection.

\section{REFERENCES}

Abebe, G., Assefa, T., Harrun, H., Mesfine, T. and Al-Tawaha, A.M. (2005). Participatory selection of drought tolerant maize varieties using mother and baby methodology: A case study in the semi arid zones of the Central Rift Valley of Ethiopia. World Journal of Agricultural Science. 1(1):22-27.

Ashley, J. (1999). Food crop and drought. In CTA Macmilian Education Limited London and Basingtokole. p133.

Badu-Apraku, B. Lum, A. F. (2010). The pattern of grain yield response of normal and quality protein maize cultivars in stress and nontress environments. Agronomy Journal. 102: 381-394.

Badu-Apraku, B., Menkir, A., Onyibe, J. E., Buah, S., Yallow, C. G., Coulibaly, N., and Crossa J. (2009). Results of the 2008 regional Maize Trials in West Africa. International 
Institute of Tropical Agriculture, Ibadan, Nigeria. p29.

Banziger, M. and de Meyer, J. (2000). Farmers' voices are heard here. CIMMYT Annual Report 1999-2000.pp 1-74.

Ceccarelli, S., Grando, S., Bailey, E., Amri, A., El-Felah, M., Nassif, F., Rezgui, S. and Yahyaoui, A. (2001). Farmer participation in barley breeding in Syria, Morocco, and Tunisia. Euphytica. 122(3): 521-536.

Chambers, R., Pacey, A. and Thrupp, L. A. (1989). Farmer First: Farmer Innovation and Agricultural Research. London, UK. Intermediate Technology Publications.

De Groote, H., Siambi, M., D. Friesen, D. and Diallo, A. (2002). Identifying Farmers' Preferences for New Maize Varieties in Eastern Africa. In: Bellon, M. R. and J. Reeves (Eds.) Quantitative Analysis of Data from Participatory Methods in Plant Breeding, CIMMYT, Mexico, DF. pp.82-103.

FAO (2005). Fertilizer use by crop in Ghana. Food and Agricultural Organization (FAO) of the Unites Nation. Rome. Italy. p47.

Kamara, A.Y., Kureh, I., Menkir, A., Kartung, P., Tarfa, B. and Amaza, P. (2006). Participatory on-farm evaluation of the performance of drought-tolerant maize varieties in the Guinea savannas of Nigeria. Journal of Food, Agriculture and Environment.4 (1), pp.192-196. www.world-food.net.

Jalleta, T. (2004). Participatory evaluation of the performance of some improved bread wheat (Triticum aestivum) varieties in the Jijiga plains of Eastern Ethiopia. Experim- mental Agriculture. 40(1): 89-97.

Mekbib, F. (2006). Farmer and formal breeding of sorghum (Sorghum bicolor (L.) Moench) and the implications for integrated plant breeding. Euphytica, 152 (2):163-176.

MoFA. (2010). Agriculture in Ghana. Facts and figures. The Statistics Research and Information Directorate (SRID) of Ministry of Food and Agriculture, December 2010.

MSDG. (1997). Climatic Data Accra; Meteorological Services Department of Ghana MSDG.

Mulatu, E. and Belete, K. (2001). Participatory varietal selection in lowland sorghum in Eastern Ethiopia: Impact on adoption and genetic diversity. Experimental Agriculture. 37(2): 211 -229 .

Nkongolo, K. K., Chinthu, K. K. L., Malusi, M. and Vokhiwa, Z. (2008). Participatory variety selection and characterization of Sorghum (Sorghum bicolor (L.) Moench) elite accessions from Malawian gene pool using farmer and breeder knowledge. African Journal of Agricultural Research. 3(4): 273-283.

Selener, D. (1997). Participatory Action Research and Social Change. The Cornell Participatory Action Research Network. Cornell University, Ithaca, NY, USA.

Snapp, S. (2002). Quantifying farmer evaluation of technologies: The Mother and Baby Trial Design. In: Bellon, M. R. and J. Reeves (Eds.) Quantitative Analysis of Data from Participatory Methods in Plant Breeding, CIMMYT, Mexico, DF. pp.9-17. 